\title{
Pengaruh Pengungkapan Corporate Social Responsibility Pada Nilai Perusahaan Dengan Likuiditas Sebagai Variabel Moderasi
}

\author{
Ida Bagus Adi Putra ${ }^{1}$ \\ Ida Bagus Putra Astika² \\ ${ }^{1,2}$ Fakultas Ekonomi dan Bisnis Universitas Udayana (Unud), Bali, Indonesia \\ e-mail: gusadiptra@gmail.com
}

\begin{abstract}
ABSTRAK
Tujuan penelitian ini adalah untuk mengetahui pengaruh pengungkapan corporate social responsibility pada nilai perusahaan dengan likuiditas sebagai variabel moderasi. Penelitian ini dilaksanakan pada perusahaan pertambangan yang terdaftar di Bursa Efek Indonesia tahun 2013-2016. Jumlah sampel yang digunakan dalam penelitian ini sebanyak 11perusahaan yang diperoleh dengan teknik non-probability sampling dengan metode purposive sampling. Teknik analisis data dilakukan dengan menggunakan teknik analisis moderated regression analysis. Berdasarkan hasil penelitian, menunjukkan bahwa Corporate Social Responsibility berpengaruh positif signifikan terhadap nilai perusahaan. Penelitian ini juga menemukan bahwa likuiditas mampu memoderasi pengaruh Corporate Social Responsibility terhadap nilai perusahaan.
\end{abstract}

Kata Kunci: corporate social responsibility, nilai perusahaan, likuiditas

\begin{abstract}
The purpose of this study was to determine the effect of corporate social responsibility disclosure on company value with liquidity as moderation variables. This research was carried out on mining companies listed on the Indonesia Stock Exchange in 2013-2016. The number of samples used in this study were 11 companies obtained by non-probability sampling technique with purposive sampling method. Data analysis techniques were carried out using moderated regression analysis analysis techniques. Based on the results of the study, shows that Corporate Social Responsibility has a significant positive effect on firm value. This study also found that liquidity was able to moderate the influence of Corporate Social Responsibility on corporate value.

Keywords: corporate social responsibility, company value, liquidity
\end{abstract}

\section{PENDAHULUAN}

Noerirawan (2012) menyatakan nilai perusahaan merupakan kondisi yang telah dicapai oleh suatu perusahaan sebagai gambaran dari kepercayaan masyarakat terhadap perusahaan setelah melalui suatu proses kegiatan selama beberapa tahun, yaitu sejak perusahaan tersebut didirikan sampai dengan saat ini. Nilai perusahaan sangat penting karena mencerminkan kinerja perusahaan dan harga saham yang dapat mempengaruhi persepsi investor terhadap perusahaan tersebut. Untuk 
Ida Bagus Adi Putra dan Ida Bagus Putra Astika. Pengaruh...

menyerap modal dari para calon investor maka suatu perusahaan harus memiliki nilai perusahaan yang baik dicerminkan dari harga saham yang tinggi. Apabila harga saham perusahaan semakin tinggi maka nilai perusahaan juga akan semakin tinggi. Hal itu juga yang menjadi keinginan para pemilik perusahaan, sebab nilai perusahaan yang tinggi mengindikasikan kemakmuran pemegang saham juga tinggi (Soliha dan Taswan, 2002).

Menurut McWilliams dan Siegel (2000), kondisi keuangan ternyata tidak cukup untuk menjamin nilai perusahaan tumbuh secara berkelanjutan. Tercapainya nilai perusahaan dapat disebabkan oleh beberapa faktor antara lain: profitabilitas, ukuran perusahaan, leverage, kebijakan dividen, good corporate governance, dan corporate social responsibility (Nandasari, 2009).Trisna Bulan (2014) Menyatakan pengguna informasi perusahaan tidak hanya melihat informasi laba, namun juga informasi lain yaitu informasi yang berhubungan dengan kegiatan sosial perusahaan dan informasi tentang perhatian perusahaan terhadap lingkungan. Perusahaan yang telah menjalankan aspek lingkungan, keuangan dan sosial akan dapat diamati dari laporan keuangannya, dan laporan perusahaan yang berhubungan dengan tiga aspek tersebut dikenal dengan sebutan laporan berkelanjutan (sustainability reporting). Wondabio (2007) menyatakan perusahaan berharap jika dengan menerapkan CSR atau tanggung jawab sosial perusahaan akan memperoleh legitimasi sosial dan akan memaksimalkan ukuran keuangan untuk jangka waktu yang panjang. Hal ini menunjukkan bahwa perusahaan yang menerapkan CSR berharap akan direspon positif oleh para pelaku pasar seperti investor dan kreditur yang nantinya dapat meningkatkan nilai perusahaan. 
Corporate Social Responsibility (CSR) merupakan tanggung jawab perusahaan atau dunia bisnis untuk berkontribusi dalam pengembangan ekonomi yang berkelanjutan dengan memperhatikan tanggung jawab sosial perusahaan dan menitikberatkan aspek ekonomi, sosial, dan lingkungan. Di Indonesia wacana mengenai kesadaran akan perlunya menjaga lingkungan dan tanggung jawab sosial telah diatur dalam Undang-Undang Perseroan Terbatas Nomor 40 pasal 74 tahun 2007 yang menjelaskan bahwa perusahaan dalam menjalankan kegiatan usaha yang berhubungan dengan sumber daya alam wajib melakukan tanggung jawab sosial dan lingkungan.

Penerapan CSR tidak lagi dianggap sebagai biaya, tetapi investasi perusahaan seiring semakin pentingnya CSR bagi perusahaan (Harjoto dan Jo, 2007). perusahaan berharap jika dengan menerapkan CSR atau tanggung jawab sosial perusahaan akan memperoleh legitimasi sosial dan akan memaksimalkan ukuran keuangan untuk jangka waktu yang panjang (Sayekti dan Wondabio, 2007). Hal ini menunjukkan bahwa perusahaan yang menerapkan CSR berharap akan direspon positif oleh para pelaku pasar seperti investor dan kreditur yang nantinya dapat meningkatkan nilai perusahaan. Oleh sebab itu, dalam mengambil keputusan investasi, banyak investor yang cukup memperhatikan CSR yang diungkapkan oleh perusahaan (Ghoul, 2011). Rakhiemah dan Agustia (2009) menyatakan perusahaan dapat memperoleh banyak manfaat dari praktik dan pengungkapan CSR apabila dipraktekkan dengan sungguh-sungguh, diantaranya : dapat mempererat komunikasi dengan stakeholders, meluruskan visi, misi, dan prinsip perusahaan terkait dengan praktik dan aktivitas bisnis internal perusahaan, 
Ida Bagus Adi Putra dan Ida Bagus Putra Astika. Pengaruh...

mendorong perbaikan perusahaan secara berkesinambungan sebagai wujud manajemen risiko dan untuk melindungi reputasi, serta untuk meraih competitive advantage dalam hal modal, tenaga kerja, supplier, dan pangsa pasar.

Penelitian mengenai CSR terhadap nilai perusahaan menunjukkan hasil yang tidak konsisten.Penelitian yang dilakukan oleh Agustina (2013), yang menunjukkan pengungkapan CSR berpengaruh positif terhadap nilai perusahaan. Penelitian Rustiarini (2010), menemukan bahwa pengungkapan CSR berpengaruh positif pada nilai perusahaan.Kusumadilaga (2010), menyatakan pengungkapan CSR berpengaruh positif terhadapnilai perusahaan. Nguyen et al., (2015) menyatakan pengungkapan CSR berpengaruh positif terhadap nilai perusahaan. Hasil penelitian Jo dan Harjoto (2007), juga menemukan bahwa pengungkapan CSR berpengaruh positif terhadap nilai perusahaan. Namun, hasil berbeda yang dilalukan oleh Ramona (2017) dalam penelitiannya menemukan bahwa CSR tidak berpengaruh pada nilai perusahaan.Dengan adanya ketidakkonsistenan hasil penelitian tersebut menunjukkan adanya variabel lain yang turut mempengaruhi hubungan CSR dengan nilai perusahaan. Sola (2008) menyatakan bahwa salah satu faktor yang berpengaruh terhadap nilai perusahaan yaitu likuiditas. Oleh karena itu, dalam penelitian ini penulis memasukkan likuiditas sebagai variabel moderasi yang diduga ikut memperkuat interaksi antara CSR dengan nilai perusahaan. Alasan penulis memilih likuiditas digunakan sebagai variabel moderasi karena likuiditas merupakan salah satu alat ukur perusahaan untuk menentukan keefektifan kinerja perusahaan. Rompas (2013) menyatakan apabila tingkat likuiditas baik, perusahaan akan efektif dalam menghasilkan labadan 
semakin baik pula posisi perusahaan tersebut dalam penggunaan aset. Secara teoritis semakin tinggi tingkat likuiditas yang dicapai perusahaan maka semakin kuat pula hubungan pengungkapan sosial (CSR) perusahaan dengan nilai perusahaan.

Likuiditas merupakan kemampuan perusahaan untuk membayar kewajiban jangka pendek perusahaan. Apabila utang perusahaan ditagih, perusahaan akan mampu untuk memenuhi utang tersebut, terutama utang yang sudah jatuh tempo. Rasio likuiditas yang baik membuat suatu jaminan bagi investor untuk melakukan investasi di perusahaan tersebut (Saleem, et al 2011). Likuiditas menjadi perhatian serius pada perusahaan karena likuiditas memainkan peranan penting dalam kesuksesan perusahaan (Owolabi, 2012). Perusahaan yang memiliki likuiditas yang baik maka akan dianggap memiliki kinerja yang baik oleh investor. Brealey dan Myers dalam Uremadu et al (2012) mengatakan bahwa Investor akan tertarik pada perusahaan yang menghasilkan uang untuk membayar utang atau kewajibannya. Hal ini akan menarik minat investor untuk menanamkan modalnya pada perusahaan.

Rompas (2013) dalam penelitiannya, menyatakan likuiditas berpengaruh positif pada nilai perusahaan. Perusahaaan akan lebih efektif dalam menghasilkan laba apabila tingkat likuiditas perusahaan baik, maka manajer perusahaan perlu menjaga tingkat likuiditas perusahaan yang akan berdampak pada nilai keuangan dan para investor akan percaya untuk berinvestasi pada perusahaan.Penelitian yang dilakukan oleh Mahendra (2012) juga menyatakan bahwa likuiditas berpengaruhpositif pada nilai perusahaan. Akan tetapi hasil yang ditemukan oleh 
Ida Bagus Adi Putra dan Ida Bagus Putra Astika. Pengaruh...

Wulandari (2014) dan Wijaya (2014) menyatakan bahwa likuiditas tidak berpengaruh pada nilai perusahaan.

Kemampuan perusahaan dengan likuiditas tinggi akan berhubungan dengan pengungkapan sosial yang tinggi. Dengan likuiditas yang tinggi berarti perusahaan mempunyai kemampuan untuk membiayai dan melakukan kegiatan yang berkaitan dengan pengungkapan CSR. Sehingga perusahaan lebih mampu untuk mengungkapkan kegiatan sosial yang dilakukan dengan lebih luas. Penelitian Widianingsih (2011) menjelaskan dalam penelitiannya bahwa likuiditas berpengaruh positif pada luas pengungkapan CSR. Sejalan dengan penelitian Suta dan Laksito (2012) likuiditas berpengaruh negatif pada luas pengungkapan CSR. Bertolak belakang dengan Adhelia (2008), Prihastuti (2008), dan Badjuri (2011) menyatakan likuiditas tidak berpengaruh pada luas pengungkapan CSR.

Waryanti (2009), dalam penelitiannya menyatakan konsep tanggung jawab sosial perusahaan yang secara umum dikenal dengan stakeholder theory adalah kumpulan dari praktik dan kebijakan yang berkaitan dengan stakeholder, pemenuhan ketentuan hukum, nilai - nilai, komitmen dunia usaha untuk berkontribusi dalam pembangunan secara berkelanjutan, serta lingkungan dan penghargaan masyarakat. Stakeholder theory dimulai dengan asumsi bahwa nilai (value) secara eksplisit dan tak dipungkiri merupakan bagian dari kegiatan usaha.

Stakeholder Theory perusahaan bukan hanya entitas yang beroperasi untuk kepentingannya sendiri, harus memberi manfaat bagi para stakeholder (kreditor, pemegang saham, supplier, konsumen, masyarakat, pemerintah, dan pihak lain). Dengan demikian, keberadaan suatu perusahaan dipengaruhi oleh dukungan yang 
diberikan oleh stakeholder pada perusahaan tersebut (Ghozali dan Chariri, 2007:409).

Teori Stakeholder mampu menjelaskan antara hubungan perusahaan dengan stakeholder-nya. Stakeholder pada dasarnya dapat mengendalikan atau memiliki kemampuan untuk mempengaruhi pemakaian sumber-sumber ekonomi yang digunakan perusahaan. Josei dan Lee (2006) menyatakan bahwa tekanan stakeholder terhadap perusahaan untuk dapat secara efektif menjalankan kegiatan lingkungannya serta tuntutan agar perusahaan menjadi akuntabel juga menyebabkan meningkatnya perusahaan yang melakukan pengungkapan lingkungan, maka power stakeholder ditentukan oleh kecil atau besarnya power yang dimiliki oleh stakeholder atas sumber tersebut. Perspektif teori ini menjelaskan masyarakat dan lingkungan merupakan stakeholder inti perusahaan yang harus diperhatikan (Andreas, 2011:5).

Pada dasarnya stakeholder mempunyai kemampuan dalam memengaruhi penggunaan dari sumber-sumber ekonomi yang digunakan perusahaan. Menurut kekuatan yang dimiliki oleh stakeholder dapat berupa kemampuan untuk membatasi akses perusahaan dalam mendapatkan sumber ekonominya. Kemampuan tersebut, perusahaan akan bekerja dengan cara-cara yang memuaskan keinginan mereka, sehingga menciptakan hubungan yang harmonis diantara perusahaan dan stakeholder demi terciptanya keadaaan yang saling menguntungkan antara keduabelah pihak (Ghozali dan Chariri, 2007).

Nilai perusahaan berperan penting dalam memproyeksikan kinerja perusahaan sehingga dapat mempengaruhi investor dan calon investor pada suatu 
Ida Bagus Adi Putra dan Ida Bagus Putra Astika. Pengaruh...

perusahaan. Nilai merupakan sesuatu yang diinginkan apabila nilai bersifat positif dalam arti menguntungkan atau menyenangkan dan memudahkan pihak yang memperolehnya untuk memenuhi kepentingan-kepentingannya yang berkaitan dengan nilai tersebut. Sebaliknya, nilai merupakan sesuatu yang tidak diinginkan apabila nilai tersebut bersifat negatif dalam arti merugikan atau menyulitkan pihak yang memperolehnya untuk mempengaruhi kepentingan pihak tersebut sehingga nilai tersebut dijauhi (Tika, 2012:40).

Nilai perusahaan dapat direfleksikan melalui harga pasar dimana harga pasar merupakan barometer dari kinerja perusahaan (Khatab et al., 2011), selain itunilai perusahaan pada dasarnya diukur dari beberapa aspek, salah satunya adalah harga pasar saham perusahaan, karena harga pasar saham perusahaan mencerminkan penilaian investor atas keseluruhan ekuitas yang dimiliki (Wahyudi, 2006). Nilai perusahaan dalam penelitian ini didefinisikan sebagai nilai pasar, seperti halnya penelitian yang pernah dilakukan oleh Nurlela dan Islahuddin (2008), karena nilai perusahaan dapat memberikan kemakmuran pemegang saham secara maksimum apabila harga saham perusahaan meningkat. Semakin tinggi harga saham, maka makin tinggi kemakmuran pemegang saham.

Rustriarini (2010), menyatakan perusahaan akan mengungkapkan suatu informasi jika informasi tersebut dapat meningkatkan nilai perusahaan. Perusahaan dapat menggunakan informasi tanggung jawab sosial sebagai keunggulan kompetitif perusahaan. Perusahaan yang memiliki kinerja lingkungan dan sosial yang baik akan direspon positif oleh investor melalui peningkatan harga saham. Apabila perusahaan memiliki kinerja lingkungan dan sosial yang 
buruk maka akan muncul keraguan dari investor sehingga direspon negatif melalui penurunan harga.

Sukamulja (2004), dalam penelitiannya menjelaskan ada beberapa rasio yang digunakan dalam mengukur nilai pasar perusahaan, misalnya market-to-book ratioprice earning ratio (PER), price flow ratio, market-to-sales ratio, danTobin's Q. Rasio Tobin's Q dianggap sebagai rasio yang memberikan informasi paling baik, karena dapat menjelaskan fenomena dalam kegiatan perusahaan seperti misalnya terjadi perbedaan cross sectional dalam pengambilan keputusan investasi dan diversifikasi, hubungan antara kepemilikan saham manajemen dengan nilai perusahaandan kebijakan kompensasi, pendanaan dan dividen. Menurut Ramadhani (2012), rasio Tobin's Q memasukkan semua unsur hutang dan modal saham perusahaan, tidak hanya saham biasa saja dan tidak hanya ekuitas perusahaan yang dimasukkan namun seluruh aset perusahaan. Untuk itu, rasio ini dinilai dapat memberikan informasi yang paling baik.

Corporate Social Responsibility (CSR) pertama kali dikenalkan oleh Bowen (1953) dimana diawal kehadirannya pelaksanaan CSR masih bersifat sukarela (Waagstein, 2011). CSR pada dasarnya adalah sebuah kebutuhan bagi korporat untuk dapat berinteraksi dengan komunitas lokal sebagai bentuk masyarakat secara keseluruhan. Kebutuhan korporat untuk beradaptasi dan guna mendapatkan kuntungan sosial dari hubungannya dengan komuitas lokal, sebuah keuntungan sosial berupa kepercayaan (trust). Definisi tersebut pada dasarnya berangkat dari filosofi bagaimana cara mengelola perusahaan baik sebagian maupun secara keseluruhan memiliki dampak positif bagi dirinya dan lingkungan. 
Ida Bagus Adi Putra dan Ida Bagus Putra Astika. Pengaruh...

Untuk itu perusahaan harus mampu mengelola bisnis operasinya dengan menghasilkan produk yang berorientasi secara positif pada masyarakat dan lingkungan (Wheeler et al., 2003)

Ramadhani (2012), menyatakan bahwa elemen-elemen CSR dapat dirangkum sebagai aktivitas perusahaan dalam mencapai keseimbangan aspek ekonomi, lingkungan, dan sosial tanpa mengesampingkan ekspektasi para pemegang saham (menghasilkan profit). Cheng dan Yulius (2011) menyatakan bahwa pengungkapan CSR merupakan proses pemberian informasi kepada kelompok yang berkepentingan tentang aktivitas perusahaan serta dampaknya terhadap sosial dan lingkungan. Pertanggungjawaban sosial suatu perusahaan diungkapkan di dalam laporan Sustainability Reporting.Sustainability Reporting meliputi pelaporan mengenai ekonomi, lingkungan dan pengaruh sosial pada kinerja organisasi (Anggraini, 2006).

Hadianto (2013), pengungkapan tanggung jawab sosial perusahaan yang sering juga disebut sebagai corporate social responsibility disclosure, corporate social reporting, social accounting, merupakan cara mengkomunikasikan informasi sosial kepada stakeholders.

Pengungkapan sosial perusahaan (corporate social disclosure) secara rinci meliputi lingkungan fisik, energi, sumber daya manusia, produk dan keterlibatan masyarakat. Standar pengungkapan CSR merujuk kepada standar yang dikembangkan oleh Global Reporting Initiatives (GRI) dimana standar GRI ini lebih memfokuskan pada standar pengungkapan berbagai kinerja ekonomi, sosial, dan lingkungan perusahaan. Hadianto (2013), menyatakan GRI adalah sebuah 
jaringan berbasis organisasi yang telah mempelopori perkembangan dunia, paling banyak menggunakan kerangka laporan keberlanjutan dan berkomitmen untuk terus-menerus melakukan perbaikan dan penerapan di seluruh dunia.

Likuiditas merupakan kemampuan perusahaan dalam memenuhi kewajiban jangka pendek dengan menggunakan dana lancar perusahaan. Suatu perusahaan dikatakan likuid jika dana lancar perusahaan yang tersedia lebih besar dari pada utang lancar. Untuk menjaga kredibilitas kepada kreditur perusahaan perlu menjaga, mengatur serta memelihara likuiditas yang baik (Wiagustini, 2014:85).

Fred Weston dalam Kasmir (2011:129) menyebutkan bahwa likuiditas adalah rasio yang menggambarkan kemampuan perusahaan dalam memenuhi kewajiban (utang) jangka pendek. Apabila utang perusahaan ditagih, perusahaan akan mampu untuk memenuhi utang tersebut, terutama utang yang sudah jatuh tempo. Rasio likuiditas yang baik membuat suatu jaminan bagi investor untuk melakukan investasi di perusahaan tersebut sehingga akan mempengaruhi struktur modal perusahaan (Muhajir dan Triyono, 2010).

Perusahaan yang memiliki likuiditas yang tinggi akan mengurangi pendanaan melalui utang. Hal ini disebabkan karena perusahaan sudah memiliki pendanaan sumber internal yang tinggi melalui aset yang likuid, sehingga semakin tinggi tingkat likuiditas suatu perusahaan makan akan menurunkan penggunaan dana eksternal perusahaan (Hudan dkk., 2012).

Teori Stakeholder mengatakan bahwa perusahaan bukanlah entitas yang hanya beroperasi untuk kepentingannya sendiri namun harus memberikan manfaat 
Ida Bagus Adi Putra dan Ida Bagus Putra Astika. Pengaruh...

bagi stakeholdernya (pemegang saham, kreditur, konsumen, supplier, pemerintah, masyarakat, analis, dan pihak lain). Dengan demikian, keberadaan suatu perusahaan sangat dipengaruhi oleh dukungan yang diberikan oleh stakeholder kepada perusahaan tersebut. Gossling dan Vocht (2007) menyatakan bahwa CSR dapat dipandang sebagai kewajiban dunia bisnis untuk menjadi akuntabel terhadap seluruh stakeholder, bukan hanya terhadap salah satu stakeholder saja.

Perusahaan diharapkan melakukan pengungkapan sosial sebagai salah satu tanggung jawab kepada para stakeholder, sehingga pasar akan memberikan apresiasi positif dengan peningkatan harga saham perusahaan (Nurlela dan Ishlahudin, 2008). Rustiarini (2010) menyatakan bahwa perusahaan akan mengungkapkan suatu informasi jika informasi tersebut dapat meningkatkan nilai perusahaan. Perusahaan dapat menggunakan informasi tanggung jawab sosial sebagai keunggulan kompetitif perusahaan. Perusahaan yang memiliki kinerja lingkungan dan sosial yang baik akan direspon positif oleh investor melalui peningkatan harga saham.

Penelitian yang dilakukan oleh Agustina (2013), yang menunjukkan pengungkapan CSR berpengaruh positif terhadap nilai perusahaan. Penelitian Rustiarini (2010), menyatakan bahwa pengungkapan CSR berpengaruh positif pada nilai perusahaan. Kusumadilaga (2010), mengatakan bahwa pengungkapan CSR berpengaruh positif pada nilai perusahaan. Fodio (2013), menyatakan bahwa pengungkapan CSR berpengaruh positif pada nilai perusahaan. Hasil penelitian Jo dan Harjoto (2007), juga menemukan bahwa pengungkapan CSR berpengaruh 
positif pada nilai perusahaan. Berdasarkan penjelasan di atas maka dapat dirumuskan hipotesis sebagai berikut:

$\mathrm{H}_{1}$ : Pengungkapan Corporate Social Responsibility berpengaruh positif pada nilai perusahaan

Likuiditas adalah kemampuan perusahaan untuk memenuhi kewajiban finansialnya dalam jangka pendek menggunakan dana lancar yang tersedia. Jika posisi dana lancar perusahaan yang tersedia lebih besar daripada utang lancar maka perusahaan selalu likuid. Perusahaan yang tidak likuid berarti perusahaan tersebut tidak sehat. Oleh karena itu, perusahaan perlu mengatur, menjaga dan memelihara likuiditas yang baik untuk menjaga kredibilitas kepada kreditur (Wiagustini, 2014:85). Teori Stakeholder menekankan bahwa perusahaan harus memenuhi kewajiban jangka pendek kepada para stakeholdernya (kreditur) sehingga pasar akan memberikan apresiasi positif yang ditunjukkan dengan peningkatan harga saham perusahaan.

Rompas (2013) dalam penelitiannya, menyatakan bahwa likuiditas berpengaruh positif pada nilai perusahaan, untuk meningkatkan laba perusahaan manajer perusahaan harus menjaga tingkat likuiditas perusahaan sehingga nantinya akan berdampak pada nilai keuangan dan para investor akan percaya untuk berinvestasi pada perusahaan. Hasil tersebut didukung oleh penelitian yang dilakukan oleh Mahendra dkk (2012) dimana dalam penelitiannya mengungkapkan bahwa likuiditas berpengaruh positif pada nilai perusahaan. Perusahaan yang memiliki likuiditas yang baik maka akan dianggap memiliki kinerja yang baik oleh investor. Brealey dan Myers dalam Uremadu et al., (2012) mengatakan bahwa Investor akan tertarik pada perusahaan yang menghasilkan 
Ida Bagus Adi Putra dan Ida Bagus Putra Astika. Pengaruh...

uang untuk membayar hutang atau kewajibannya. Hal ini akan menarik minat investor untuk menanamkan modalnya pada perusahaan.Berdasarkan uraian tersebut, maka hipotesis yang diajukan dalam penelitian ini.

$\mathrm{H}_{2}$ : Likuiditas memperkuat pengaruh Corporate Social Responsibility pada nilai perusahaan.

\section{METODE PENELITIAN}

Lokasi penelitian ini adalah perusahaan pertambangan yang terdaftar di Bursa Efek Indonesia tahun 2013-2016 yang diakses melalui situs resmi Bursa Efek Indonesia (www.idx.co.id). Alasan dipilihnya perusahaan pertambangan dikarenakan perusahaan pertambangan merupakan perusahaan yang kegiatan operasinya berkaitan erat dengan eksploitasi sumber daya alam serta memiliki dampak terkaitan kerusakan lingkungan sekitar wilayah lingkungan pertambangan.

Selain itu sektor pertambangan juga sektor yang memiliki nilai kapitasilasi yang besar di bandingkan sektor lain sehingga membuat sektor pertambangan ini merupakan sektor yang kuat dan sangat diminati oleh investor.

Populasi pada penelitian ini adalah perusahaan-perusahaan pertambangan yang terdaftar di Bursa Efek Indonesia tahun 2013-2016.Sampel pada penelitian ini diambil dengan menggunakan teknik purposive sampling dengan tujuan untuk mendapatkan sampel yang sesuai dengan kriteria yang ditentukan.Pada penelitian ini metode yang digunakan adalah metode observasi non partisipan. Terdapat 11 perusahaan yang memenuhi kriteria penentuan sampel. Berikut ini adalah daftar perusahaan yang memenuhi kriteria sampel yang telah ditentukan oleh peneliti: 
Tabel 1.

Total Sampel Perusahaan Pertambangan yang Terdaftar di BEI

Periode 2013-2016

\begin{tabular}{llc}
\hline \multicolumn{1}{c}{ No } & \multicolumn{1}{c}{ Nama Perusahaan } & Kode \\
\hline 1 & PT. Adaro Energy Tbk & ADRO \\
2 & PT. Aneka Tambang (Persero) Tbk & ANTM \\
3 & PT. Bayan Resources Tbk & BYAN \\
4 & PT. Darma Henwa Tbk & DEWA \\
5 & PT. Elnusa Tbk & ELSA \\
6 & PT. Energi Mega Persada Tbk & ENRG \\
7 & PT. Indo Tambangraya Megah Tbk & ITMG \\
8 & PT. Medco Energi Internasional Tbk & MEDC \\
9 & PT. Tambang Batubara Bukit Asam Tbk & PTBA \\
10 & PT. Petrosea Tbk & PTRO \\
11 & PT. Timah (Persero) Tbk & TINS \\
\hline
\end{tabular}

Sumber: Data diolah, 2018

Teknik analisis yang digunakan pada penelitian ini yaitu dengan menggunakan teknik Moderated Regression Analysis (MRA) dengan menggunakan program SPSS. Teknik ini digunakan untuk melihat pengaruh corporate social responsibility pada nilai perusahaan dengan likuiditas sebagai variabel pemoderasi. Pengujian ini bertujuan untuk mengetahui pengaruh corporate social responsibility pada nilai perusahaan dengan likuiditas sebagai variabel moderasi. Aplikasi khusus regresi linear berganda yang mengandung unsur interaksi dalam persamaan regresinya. Secara sistematis persamaan regresi yang diperoleh yakni:

$$
\mathrm{Y}=\alpha+\beta_{1} \mathrm{X}_{1}+\beta_{2} \mathrm{M}_{1}+\beta_{3} \mathrm{X}_{1} * \mathrm{M}_{1}
$$

Tabel 2.

Klasifikasi Variabel Moderasi

\begin{tabular}{ccc}
\hline No. & Tipe Moderasi & Koefisien \\
\hline 1. & Pure Moderasi & $\mathrm{b}_{2}$ non significant \\
& $\mathrm{b}_{3}$ significant \\
& & $\mathrm{b}_{2}$ significant \\
2. & $\mathrm{~b}_{3}$ significant \\
& Quasi Moderasi & $\mathrm{b}_{2}$ non significant \\
3. & $\mathrm{~b}_{3}$ nonsignificant \\
& Homologiser Moderasi & $\mathrm{b}_{2}$ significant \\
4. & Predictor Moderasi & $\mathrm{b}_{3}$ non significant \\
\hline
\end{tabular}


Ida Bagus Adi Putra dan Ida Bagus Putra Astika. Pengaruh...

\section{HASIL DAN PEMBAHASAN}

Populasi dari penelitian ini adalah perusahaan pertambangan yang terdaftar di Bursa Efek Indonesia periode 2013 - 2016. Dengan menggunakan purposive sampling ini, dari 41 perusahaan pertambangan sebagai populasi didapatkan 11 perusahaan yang memenuhin kriteria tersebut. Adapun perusahaan yang memenuhi kriteria seperti tabel dibawah ini:

Tabel 3.

Proses Seleksi Sampel Penelitian

\begin{tabular}{clc}
\hline No. & \multicolumn{1}{c}{ Keterangan } & Jumlah \\
\hline $1 \quad \begin{array}{l}\text { Perusahaan pertambangan yang terdaftar di BEI secara berturut-turut selama } \\
\text { tahun 2013-2016. }\end{array}$ & 41 \\
$\quad \begin{array}{l}\text { Tidak menerbitkan laporan tahunan lengkap secara berturut-turut selama } \\
\text { tahun 2013-2016. }\end{array}$ & $(9)$ \\
$\quad$ Perusahaan pertambangan yang tidak menggunakan mata uang rupiah & $(21)$ \\
Perusahaan pertambangan yang terpilih sebagai sampel penelitian & 11 \\
Jumlah pengamatan selama tahun 2013-2016 & 44 \\
\hline
\end{tabular}

Sumber: Data diolah, 2018

Deskripsi variabel penelitian menyampaikan informasi mengenai karakteristik variabel-variabel penelitian yang terdiri dari jumlah pengamatan, nilai minimum, nilai maksimum, nilai rata dan standar deviasi. Dalam penelitian ini dilakukan transformasi data karena pada uji asumsi klasik ada pengujian yang tidak lolos yaitu pada uji normalitas maka pengujian dapat diteruskan dengan transformasi data. Tabel berikut memperlihatkan hasil analisis statistik deskriptif variable penelitian ini.

Tabel 4.

Statistik Deskripstif Variabel-Variabel Penelitian

\begin{tabular}{lrrrrr}
\hline & N & \multicolumn{1}{c}{ Minimal } & Maksimal & Rata-Rata & \multicolumn{1}{c}{ Std. Deviasi } \\
\hline Nilai Perusahaan (Y) & 44 &, 393 & 18,995 & 2,233 & 2,757 \\
CSR $\left(\mathrm{X}_{1}\right)$ & 44 &, 417 &, 886 &, 634 &, 116 \\
Likuiditas $\left(\mathrm{M}_{1}\right)$ & 44 &, 094 & 1,600 &, 665 &, 478 \\
Valid N (listwise) & 44 & & & & \\
\hline Sumber: Data diolah 2018 & & & & &
\end{tabular}


Berdasarkan tabel statistik deskriptif diatas, terdapat berbagai informasi deskripsi dari variabel yang digunakan. Output tampilan SPSS menunjukkan jumlah sampel yang digunakan sebanyak 44 (n). Variabel nilai perusahaan (Y) memiliki nilai terendah (minimal) sebesar 0,393 yang dimiliki oleh PT. Timah (Persero) Tbk pada tahun 2013, sedangkan nilai tertinggi (maksimal) sebesar 18,995 yang dimiliki oleh PT. Energi Mega Persada Tbk pada tahun 2016, dengan rata-rata sebesar 2,233 dan simpangan baku (standar deviasi) sebesar 2,757. Standar deviasi untuk nilai perusahaan adalah 2,757 yang memiliki makna dimana terjadi penyimpangan nilai perusahaan pada nilai rata-ratanya sebesar 2,757

Variabel CSR $\left(\mathrm{X}_{1}\right)$ memiliki nilai terendah (minimal) sebesar 0,417 yang dimiliki oleh PT. Bayan Resources Tbk pada tahun 2013, sedangkan nilai tertinggi (maksimal) sebesar 0,886 yang dimiliki oleh PT. Tambang Batubara Bukit Asam Tbk pada tahun 2014, 2015 dan 2016, dengan rata-rata (mean) sebesar 0,634 dan simpangan baku (standar deviasi) sebesar 0,113. Standar deviasi standar untuk CSR adalah 0,116 yang memiliki makna dimana terjadi penyimpangan nilai CSR p ada nilai rata-ratanya sebesar 0,116 .

Variabel Likuiditas $\left(\mathrm{M}_{1}\right)$ memiliki nilai terendah (minimum) sebesar 0,094 yang dimiliki oleh PT. Indo Tambangraya Megah Tbk pada tahun 2015, sedangkan nilai tertinggi (maksimum) sebesar 1,6 yang dimiliki oleh PT. Aneka Tambang (Persero) Tbk pada tahun 2015, dengan rata-rata (mean) sebesar 0,665 dan simpangan baku (standar deviasi) sebesar 0,478. Standar deviasi untuk likuiditas adalah 0,478 yang memiliki makna terjadi penyimpangan nilai ROE pada nilai rata-ratanya sebesar 0,478 . 
Pengujian data dalam penelitian ini menggunakan teknik analisis regresi linier berganda. Perhitungan koefisien regresi linier berganda dilakukan dengan analisis regresi melalui software SPSS 18.0 for Windows, diperoleh hasil yang ditunjukan pada Tabel 5. berikut

Tabel 5.

Hasil Analisis Regresi Moderasi

\begin{tabular}{|c|c|c|c|c|c|c|}
\hline \multirow{2}{*}{\multicolumn{2}{|c|}{ Model }} & \multicolumn{2}{|c|}{$\begin{array}{l}\text { Unstandardized } \\
\text { Coefficients }\end{array}$} & \multirow{2}{*}{$\begin{array}{c}\text { Standardized } \\
\text { Coefficients } \\
\text { Beta }\end{array}$} & \multirow[t]{2}{*}{$\mathbf{t}$} & \multirow[t]{2}{*}{ Sig. } \\
\hline & & B & Std. Error & & & \\
\hline \multirow[t]{4}{*}{1} & (Constant) & , 126 & ,119 & & 1,058 & 296 \\
\hline & $\operatorname{CSR}\left(\mathrm{X}_{1}\right)$ & 357 & ,132 & ,357 & 2,713 & ,010 \\
\hline & Likuiditas $\left(\mathrm{M}_{1}\right)$ & 101 & 119 & 101 & 846 & ,403 \\
\hline & $\mathrm{X}_{1} \cdot \mathrm{M}_{1}$ & 420 & 125 & 425 & 3,345 & ,002 \\
\hline
\end{tabular}

Berdasarkan hasil analisis regresi linier berganda seperti yang disajikan pada Tabel ,maka persamaan strukturalnya adalah sebagai berikut :

$$
\begin{aligned}
& Y=\alpha+\beta_{1} X_{1}+\beta_{2} M_{1}+\beta_{3} X_{1} * M_{1} \\
& Y=0,126+0,357 X_{1}+0,101 M_{1}+0.420 X_{1} * M_{1}+e
\end{aligned}
$$

Berdasarkan pernyataan diatas, dapat dijelaskan bahwa nilai konstanta 0,126 menunjukkan bahwa bila CSR dan likuiditas sama dengan nol, maka nilai perusahaan akan meningkat sebesar 0,126 satuan.Nilai koefisien regresi CSR $\left(\mathrm{X}_{1}\right)$ sebesar 0,357 menunjukkan bahwa bila CSR naik satu satuan, maka nilai perusahaan akan mengalami peningkatan sebesar 0,357 satuan dengan asumsi variabel lainnya konstan.Nilai koefisien regresi likuiditas $\left(\mathrm{M}_{1}\right)$ sebesar 0,101 menunjukkan bahwa bila likuiditas naik satu satuan, maka nilai perusahaan akan mengalami peningkatan sebesar 0,101 satuan dengan asumsi variabel lainnya konstan. Nilai koefisien regresi CSR*Likuiditas $\left(\mathrm{X}_{1} \cdot \mathrm{M}_{1}\right)$ sebesar 0,42 menunjukkan bahwa bila interaksi antara CSR dengan likuiditas naik satu satuan, 
maka nilai perusahaan akan mengalami peningkatan sebesar 0,42 satuan dengan asumsi variabel lainnya konstan.

Uji kesesuaian model regresi bertujuan untuk mengetahui apakah semua variabel bebas yang diidentifikasi (CSR, likuiditas, dan variabel interaksi antara CSR dengan likuiditas) tepat digunakan memprediksi nilai perusahaan. Uji ini sering juga disebut dengan uji $\mathrm{F}$.

Tabel 6.

\begin{tabular}{llrrrrr}
\multicolumn{7}{c}{ Hasil Uji F } \\
\hline Model & & $\begin{array}{c}\text { Sum of } \\
\text { Squares }\end{array}$ & df & $\begin{array}{c}\text { Mean } \\
\text { Square }\end{array}$ & F & Sig. \\
\hline $\mathbf{1}$ & Regresi & 18,353 & 3 & 6,118 & 11,831 &, $000^{\mathrm{a}}$ \\
& Residual & 20,683 & 40 &, 517 & & \\
& Total & 39,036 & 43 & & & \\
\hline
\end{tabular}

Sumber: Data diolah, 2018

Hasil uji $\mathrm{F}$ (Ftest) menunjukkan bahwa nilai signifikansi $\mathrm{P}$ value 0,000 yang lebih kecil dari $\alpha=0,05$, ini berarti model yang digunakan pada penelitian ini adalah layak. Hasil ini memberikan makna bahwa seluruh variabel independen yaitu CSR, likuiditas, dan variabel interaksi antara CSR dengan likuiditas mampu memprediksi atau menjelaskan fenomena nilaiperusahaan yang terdapat pada perusahaan pertambangan yang terdaftar di Bursa Efek Indonesia (BEI) pada tahun 2013-2016. Hal ini berarti model dapat digunakan untuk analisa lebih lanjut atau dengan kata lain model dapat digunakan untuk memproyeksikan karena hasil goodness of fitnya baik dengan nilai signifikansi $\mathrm{P}$ value 0,001 .

Uji koefisien determinasi $\left(\mathrm{R}^{2}\right)$ digunakan untuk mengetahui dan mengukur kemampuan model dalam menerangkan variasi variabel independen. Peneliti menggunakan nilai adjusted $\mathrm{R}^{2}$ pada saat mengevaluasi yang mana model regresi terbaik, karena tidak seperti $\mathrm{R}^{2}$, nilai adjusted $\mathrm{R}^{2}$ (koefisien determinasi yang 
telah disesuaikan) dapat naik atau turun apabila satu variabel independen ditambahkan ke dalam model.

Tabel 7.

Hasil Uji Koefisien Determinasi

\begin{tabular}{lrrrr}
\hline Model & R & R Square & Adjusted R Square & $\begin{array}{c}\text { Std. Error of the } \\
\text { Estimate }\end{array}$ \\
\hline $\mathbf{1}$ &, $686^{\mathrm{a}}$ &, 470 &, 430 &, 71907457 \\
\hline Sumber: Data diolah, 2018 & & & &
\end{tabular}

Hasil uji koefisien determinasi dalam Tabel menunjukkan besarnya nilai adjusted $\mathrm{R}^{2}$ adalah sebesar 0,430 . Ini berarti variasi nilai perusahaandapat dipengaruhi secara signifikan oleh variabel CSR, Likuiditas, dan variabel interaksi antara CSR dengan likuiditas sebesar 43 persen sedangkan sisanya sebesar 57 persen dijelaskan oleh faktor-faktor lain.

Berdasarkan analisis data menggunakan Analisis Regresi moderasi hasil pengujian menunjukan Variabel Pengungkapan Corporate Social Responsibility mempunyai nilai signifikansi $0,010<0,05$, yang berarti bahwa pengungkapan CSR berpengaruh positif dan signifikan terhadap nilai perusahaan pertambangan yang terdaftar di Bursa Efek Indonesia (BEI) tahun 2013-2016. Maka dari itu perusahaan harus wajib memperhatikan tanggung jawab sosial lingkungan dan dimensi ekonomi karena hal itu menjamin nilai perusahaan akan tumbuh secara berkelanjutan. CSR terbukti mampu mempengaruhi keadaan perusahaan yang berdampak pada nilai perusahaan. Hal tersebut sesuai dengan teori bahwa perusahaan bukanlah entitas yang hanya beroperasi untuk kepentingan sendii namun harus memberikan manfaat bagi stakeholdernya. Kepuasan stakeholder dapat dicapai dengan cara, salah satunya adalah peningkatan tanggung jawab sosial yang berkelanjutan. 
Hasil penelitian ini sejalan dengan penelitian yang dilakukan oleh Penelitian yang dilakukan oleh Agustina (2013), yang menunjukkan pengungkapan CSR berpengaruh positif terhadap nilai perusahaan. Penelitian Rustiarini (2010), menemukan bahwa pengungkapan CSR berpengaruh positif pada nilai perusahaan. Kusumadilaga (2010), mengatakan bahwa dengan pengungkapan CSR berpengaruh positif pada nilai perusahaan. Hasil penelitian Jo dan Harjoto (2007), juga menemukan bahwa pengungkapan CSR berpengaruh positif pada nilai perusahaan.

Hasil pengujian variabel Pengungkapan Corporate Social Responsibility dengan likuiditas sebagai variabel pemoderasi menunjukan tingkat signifikansi $0,002<0,05$, maka likuiditas mampu memoderasi hubungan Pengungkapan Corporate Social Responsibility pada nilai perusahaan. Perusahaan harus memenuhi kewajiban jangka pendek kepada para stakeholdernya (kreditur) sehingga pasar akan memberikan apresiasi positif yang ditunjukkan dengan peningkatan harga saham perusahaan. Kemampuan perusahaan dengan likuiditas tinggi akan berhubungan dengan pengungkapan sosial yang tinggi. Dengan likuiditas yang tinggi berarti perusahaan mempunyai kemampuan untuk membiayai dan melakukan kegiatan yang berkaitan dengan pengungkapan sosial (CSR). Sehingga perusahaan lebih mampu untuk mengungkapkan kegiatan sosial yang dilakukan dengan lebih luasyang berdampak pada meningkatnya nilai perusahaan

Berdasarkan pembahasan yang telah diuraikan terdapat beberapa implikasi penelitian yang dapat dimanfaatkan adalah penelitian ini menghasilkan simpulan 
mengenai bagaimana pengaruh CSR terhadap nilai perusahaan dengan likuiditas sebagai variabel moderasi. Penelitian ini membuktikan Stakeholder Theory yang menyatakan bahwa perusahaan bukanlah entitas yang hanya beroperasi untuk kepentingannya sendiri namun harus memberikan manfaat bagi para stakeholder (pemegang saham, kreditor, konsumen, supplier, pemerintah, masyarakat, dan pihak lain). Dengan demikian, maka keberadaan suatu perusahaan sangat dipengaruhi oleh dukungan yang diberikan oleh stakeholder kepada perusahaan tersebut. Apabila perusahaan dapat memaksimalkan manfaat yang diterima stakeholder maka akan timbul kepuasan bagi stakeholder yang akan meningkatkan nilai perusahaan. Hal ini ditunjukan dengan koefisien regresi yang bernilai positif.

Penelitian ini diharapkan akan memberikan kontribusi positif bagi semua pihak khususnya pihak investor dan perusahaan. Bagi pihak perusahaan hendaknya bersungguh-sungguh dalam penerapan pengungkapan CSR. Bagi pihak investor dalam berinvestasi tetap memperhatikan rasio likuiditas dan penerapan CSR dari perusahaan dan investor yang akan berinvestasi juga tetap mempertimbangkan masing-masing aspek yaitu likuiditas dan CSR, hal ini penting karena aspek tersebut dapat memengaruhi keputusan investor dalam berinvestasi.

\section{SIMPULAN}

Dilihat dari hasil pembahasan dan analisis yang telah di paparkan sebelumnya maka dapat disimpulkan bahwa Corporate Social Responsibility berpengaruh 
positif terhadap nilai perusahaan. Hasil penelitian ini menunjukkan bahwa besar kecilnya praktik CSR mempengaruhi peningkatan nilai perusahaan.

Likuiditas terbukti mampu memperkuat pengaruh Pengungkapan Corporate Social Responsibility pada nilai perusahaan. Perusahaan perlu mengatur, menjaga dan memelihara likuiditas yang baik untuk menjaga kredibilitas kepada kreditur (Wiagustini, 2014:85). Teori Stakeholder menekankan bahwa perusahaan harus memenuhi kewajiban jangka pendek kepada para stakeholdernya (kreditur) sehingga pasar akan memberikan apresiasi positif yang ditunjukkan dengan peningkatan harga saham perusahaan.

Hasil penelitian ini memberikan tambahan wawasan mengenai penelitian yang telah dilakukan dengan melihat beberapa teori. Adakah beberapa saran yang diajukan dalam penelitian ini, yaituinvestor harus mempertimbangkan berbagai aspek ketika akan melakukan investasi di perusahaan, salah satunya dari CSR. Investor dalam memutuskan akan berinvestasi, sebaiknya memilih pada perusahaan yang telah menerapkan tanggung jawab sosialnya secara konsisten. Berdasarkan hasil penelitian ini, kualitas pengungkapan CSR masih rendah sehingga investor harus selektif dalam memilih perusahaan yang akan ditanamkan modalnya. Selanjutnya investor sebaiknya memperhatikan rasio likuiditas perusahaan yang mengungkapkan CSR secara konsisten dalam memilih perusahaan yang akan ditanamkan modalnya.

Perusahaan hendaknya lebih memperhatikan penerapan dan pelaporan CSR berdasarkan standar yang telah dikeluarkan Global Reporting Index (GRI). Dengan demikian, diharapkan dapat meningkatkan Nilai Perusahaan.Perusahaan 
Ida Bagus Adi Putra dan Ida Bagus Putra Astika. Pengaruh...

hendaknya lebih memperhatikan rasio likuiditas perusahaan sehingga nilai perusahaan akan semakin meningkat guna menarik investor untuk berinvestasi pada perusahaan.

\section{REFERENSI}

Adhelia, Hexa. 2008. Analisis Faktor-Faktor yang Mempengaruhi Kelengkapan Pengungkapan Sosial dalam Laporan Tahunan Perusahaan (Studi pada Perusahaan High Profile yang Terdaftar di BEI). JurnalAkuntansi Fakultas Ekonomi Universitas Brawijaya

Agustina, Silvia. 2013. Pengaruh Profitabilitas dan Pengungkapan Corporate Social Responsibility Terhadap Nilai Perusahaan (Studi Empiris pada Perusahaan Manufaktur yang Terdaftar di Bursa Efek Indonesia). Skripsi Universitas Negeri Padang

Anggraini, Retno. 2006. Pengungkapan Informasi Sosial dan Faktor-faktor yang Mempengaruhi Pengungkapan Informasi Sosial dalam Laporan Keuangan Tahunan. Simposium Nasional Akuntansi IX Padang, 23-26 Agustus 2006

Andreas, Lako. 2011. Dekonstruksi CSR dan Reformasi Paradigma Bisnis dan Akuntansi. Jakarta : Erlangga

Badjuri, Achmad. 2011. Faktor-faktor Fundamental, Mekanisme Corporate Governance, Pengungkapan Corporate Social Responsibility (CSR) Perusahaan Manufaktur dan Sumber Daya Alam di Indonesia. Dinamika Keuangan dan Perbankan. Universitas Stikubank.

Brealey, Richard A, Stewart C. Myers, Alan J. Marcus. 2008. Dasar-dasar Manajemen Keuangan Perusahaan. Jakarta: Erlangga

Cheng Ming Chang dan Zuwei Ching Tzeng. 2011. The Effect of Leverage on Firm Value and How The Firm Financial Quality Influence on This Effect. World Journal Of Mangement, 3(2): h: 30-53.

Fodio, Musa Inuwa, Abdullahi Musa- bu Abdiss Amad dan Victor Chiedu Oba. 2013. Corporate Social Responsibility and Firm Value in Quoted Nigerian Financial Services. International Journal of Finance and Accounting, 2(7), pp: 331-340.

Ghoul, Sadok El, Omrane Guedhami, Chuck C. Y. Kwok, Dev R. Mishra. 2011. Does Corporate Social Responsibility affect the cost of capital? Journalof Banking \& Finance, 35 (9), pp. 2388-2406 
Gossling, Tobias dan Chris Vocht. 2007. Social Role Conceptions and Corporate Social Responsibility Policy Success. Journal of Business Ethics, 74, pp: 363372.

Hadianto, M. L. 2013. Analisis Pengaruh Kinerja Keuangan Terhadap Nilai Perusahaan Dengan Pengungakapan CSR dan GCG Sebagai Variabel Pemoderasi. Skripsi. Universitas Diponegoro, Semarang.

Harjoto, Maretno A, dan Hoje Jo. (2007). Corporate Govermance and Firm Value The Impact of CSR, Social Science Research Network. Journal of Business Ethics.

Herawaty, Vinola. 2008. Peran Praktek Corporate Governance sebagai Moderating Variabel dari Pengaruh Earnings Management Terhadap Nilai Perusahaan. Simposium Nasional Akuntansi 11. Pontianak.

Hudan, Diandono. 2012. Pengaruh Mekanisme Good Corporate Governance (GCG) pada Kinerja Perusahaan Yang Masuk Kelompok Jakarta Islamic Indeks (JII) Periode 2006 2011. Jurnal Fakultas Syari'ah dan Hukum Universitas Islam Negeri Sunan Kalijaga, Yogyakarta

Indrawan, Danu Candra. 2011. Pengaruh Corporate Social Responsibility terhadap kinerja perusahaan. Skripsi Universitas Diponegoro, Semarang

J. Fred Weston, Eugene. 2004. Dasar-dasar Manajemen Keuangan. Edisi ketujuh. Penerbit Ertangga

Jo, Hoje and Maretno A. Harjoto. 2011. Corporate Governance and Firm Value: The Impact of Corporate Social Responsibility". Journal of Business Ethics, Vol. 103. Hal. 351-383. USA. Santa Clara University and Pepperdine University

Jose, A. and Shang-Mei L.2006. Envorotmental Reporting of Global Corporations : A Content Analysis Based on Website Disclousure. Journal of Business Ethics, 72, pp: 307-321.

Khatab, Humera, Masood, Maryam. Zaman, Khalid. Saleem, Sundas and Saeed, Bilal. 2011. Corporate Governance and Firm Performance:A Case study of Karachi Stock Market. International Journal of Trade, Economics and Finance

Kusumadilaga, Rimba, 2010. Pengaruh CSR Terhadap Nilai Perusahaan Dengan Profitabilitas Sebagai Variabel Moderating. Skripsi Fakultas Ekonomi Universitas Diponegoro. 
Mahendra Dj, Alfredo, Luh Gede Sri Artini, AA Gede Suarjaya. 2012. Pengaruh Kinerja Keuangan Terhadap Nilai Perusahaan Pada Perusahaan Manufaktur Di Bursa Efek Indonesia. Jurnal Manajemen, Strategi Bisnis, dan Kewirausahaan Fakultas Ekonomi Universitas Udayana.

McWilliams, Abagail and Donald Siegel. 2000. Corporate Social Responsibility and Financial Performance: Correlation or Misspecification?. Journal of Strategic Management, Vol. 21 No. 5. 603-609.

Muhajir dan Triyono. 2011. Faktor-Faktor Yang Mempengaruhi Struktur Modal Perusahaan Manufaktur Pada Bursa Efek Indonesia Periode 2005-200. Jurnal Fakultas Ekonomi Universitas Muhammadiyah, Semarang

Nandasari, Kharisma. 2009. Pengaruh Corporate Social Responsibility (CSR) terhadap Nilai Perusahaan (Studi Empiris pada Perusahaan Tambang yang Listing di BEI. Skripsi Sarjana Akuntansi pada Universitas Negeri Yogyakarta

Nurlela, R dan Islahuddin. 2008. Pengaruh Corporate Social Responsibility Terhadap Nilai. Jurnal Sekolah Tinggi Ilmu Ekonomi Indonesia (STIESIA), Surabaya

Nurlela, Rika dan Islahuddin. 2008. Pengaruh Corporate Social Responsibility terhadap Nilai Perusahaan dengan Prosentase Kepemilikan Manajemen sebagai Variabel Moderating. Simposium Nasional Akuntansi XI. Pontianak, 23-24 Juli.

Nguyen, Bich Thi, Hai Thi Thanh Tran, Oanh Huang Le, Phuoc Thi Nguyen, Thien Hiep Trinh and Viet Le. 2015. Association between Corporate Social Responsibility Disclosures and Firm Value - Empirical Evidence from Vietnam. International Journal of Accounting and Financial Reporting, 5(1), pp: 212-228.

Owolabi, A. B. 2012. Effect of organizational justice and organizational environment on turnover intention of health workers in Ekiti State Nigeria. Research in world economy, 3(1), 28-34. DOI. 10.5430/rwe.v3n1p28

Prihatiningtias, YW. dan Dayanti, N. 2014. Corporate Social Responsibility Disclosure and Firm Financial Performane in Mining and Natural Resources Industry. The International Journal of Accounting and Business Society, 22 (1): 35-58.

Ramadhani, Laras Surya dan Basuki Hadiprajitno. 2012. Pengaruh Corporate Social Responsibility terhadap Nilai Perusahaan dengan Prosentase Kepemilikan Manajemen sebagai Variabel Moderating pada Perusahaan 
Manufaktur yang Terdaftar di BEI. Jurnal Akuntansi dan Auditing Universitas Diponegoro

Rakhiemah, Aldilla Noor, Dian Agustia. 2009. Pengaruh Kinerja Lingkungan terhadap Corporate Social Responsibility (CSR) Disclosure dan Kinerja Financial perusahaan manufaktur yang terdaftar di Bursa Efek Indonesia. Jurnal Universitas Airlangga, Surabaya

Rompas, Gisela Prisilia. 2013. Likuiditas, Solvabilitas dan Rentabilitas Terhadap Nilai Perusahaan BUMN yang Terdaftar di Bursa Efek Indonesia. Jurnal EMBA

Rustiarini, Ni Wayan. 2010. Pengaruh Corporate Governance pada Hubungan Corporate Social Responsibility dan Nilai Perusahaan. Simposium Nasional Akuntansi XIII Purwokerto.

Saleem, Qosim dan Rahman, Ramiz Ur. 2011. Impact of Likuidity Ratios on Profitability (Case of Oil ang Gas Companies of Pakistan). Interdiciplinary Journal of Research ini Business. Vol I. Issue 7, July

Soliha, Evis dan Taswan. 2002. Pengaruh Kebijakan Hutang Terhadap Nilai Perusahaan Serta Faktor yang Memengaruhinya. Jurnal Bisnis dan Ekonomi, STIE Stikubank, Semarang

Sayekti, Y. dan L. S. Wondabio. 2007. Pengaruh CSR Disclosure terhadap Earning Response Coefficient (Studi Empiris pada Perusahaan yang Terdaftar di Bursa Efek Jakarta). Simposium Nasional Akuntansi X Makassar

Sukamulja, Sukmawati. 2004, Good Corporate Governance di Sektor Keuangan: Dampak Good Corporate Governance Terhadap Kinerja Keuangan. Jurnal Fakultas Ekonomi Universitas Atma Jaya, Yogyakarta

Suta, A. Y. dan H. Laksito. 2012. Analisis Faktor-faktor yang Mempengaruhi Luas Pengungkapan Informasi Sukarela Laporan Tahunan (Studi Empiris pada Perusahaan Manufaktur yang terdaftar di Bursa Efek Indonesia Tahun 2008-2010), Jurnal Akuntansi Diponegoro

Tika, Moh Pabundu. 2012. Budaya Organisasi dan Peningkatan Kinerja Perusahaan. Jakarta: Bumi Aksara.

Trisna Bulan, A.A.Ayu \& I. B. Putra Astika. 2014. Moderasi Corporate Social Responsibility Terhadap Pengaruh Kinerja Keuangan Pada Nilai Perusahaan. Jurnal Akuntansi Universitas Udayana 
Ida Bagus Adi Putra dan Ida Bagus Putra Astika. Pengaruh...

Waagstein, P.R. 2011. The mandatory corporate social responsibility in Indonesia: problems and implications. Journal of Business Ethics, 98 (-): 455-466

Wahyudi, Akdon H. 2006. Manajemen Konflik dalam Organisasi. Bandung: Alfabeta, Anggota Ikatan Penerbit Indonesia (IKAPI).

Waryanti, 2009. Pengaruh Karakteristik Perusahaan Terhadap Pengungkapan Sosial Pada Perusahaan Manufaktur di Bursa Efek Indonesia. Skripsi Universitas Diponegoro, Semarang.

Wheeler, D., Colbert, B., \& Freeman, R.E. 2003. Focusing on Value: Reconciling Corporate Social Responsibility, Sustainability and a Stakeholder Approach in a Network World. Journal of General Management

Wijaya, I.B.N.P. 2014. Pengaruh Likuiditas dan Kepemilikan Instusional terhadap Nilai Perusahaan Dimoderasi oleh Kebijakan Deviden. E-Jurnal Manajemen Universitas Udayana

Wulandari, D. R. 2014. Pengaruh Profitabilitas, Operating Leverage, Likuiditas terhadap Nilai Perusahaan dengan Struktur Modal sebagai Intervening. Jurnal Akuntansi Universitas Negeri Semarang

Wiagustini, Luh Putu. 2014. Dasar-dasar Manajemen Keuangan. Denpasar: Udayana University Press.

Widianingsih, Y. P. N. 2011. Pengaruh Likuiditas dan Profitabilitas terhadap Luas Pengungkapan Sukarela Laporan Tahunan Studi Empiris pada Perusahaan Manufaktur yang terdaftar di Bursa Efek Indonesia. Politeknosains Vol.X No.2, Surakarta.

Wibisono, Yusuf. 2007. Membedah Konsep dan Aplikasi Coorporate Social Responsibility. Gresik : Fascho Publishing. 